\title{
Design of Science Process Skill Approach-Based Laboratory Work Instruction
}

\author{
Veri Firmansyah'1, Friska Septiani Silitonga ${ }^{1}$, Fitriah Khoirunnisa ${ }^{1}$, \& Sri Setiawaty ${ }^{\star}$ \\ ${ }^{1}$ Universitas Maritim Raja Ali Haji. Jl. Politeknik Senggarang, Tanjungpinang, Indonesia \\ 2Universitas Malikussaleh, Aceh Utara, Indonesia \\ verifirmandbl@gmail.com; fitriahk@umrah.ac.id; friska.septiani89@gmail.com; sri.setiawaty@unimal.ac.id \\ ${ }^{*}$ Corresponding Author
}

How to Cite : Firmansyah, V., Silitonga, F., S., Khoirunnisa, F., \& Setiawaty, S. (2020). Design of Science Process Skill Approach-Based Laboratory Work Instruction. International Journal for Educational and Vocational Studies, 2 (2), 153-157. DOI: https://doi.org/10.29103/ijevs.v2i2.2280

\section{ARTICLE HISTORY}

Received:13 October 2019

Revised: 27 December 2019

Accepted: 25 January 2020

\section{KEYWORDS}

Lab Work Instruction; Science Process Skills Approach; Research And Development

\section{ABSTRACT}

The development of a Science Process Skills Approach-based Laboratory Work Instruction has been conducted on Heat of Reaction topic. The subject of the research is the students of class XI in Senior High School 2 Tanjungpinang. The research aims to determine the feasibility of laboratory work instruction in terms of the validity and practicality categories. In the category of validity, there are five aspects studied including the aspects of content feasibility, grammar, presentation, graphical design, and science process skills. The validation results obtained from three validators was $92.46 \%$ (very valid category). In the practicality category was conducted on 40 students. In this category, there are seven aspects studied, namely aspects of observing, classifying, interpreting, determining hypotheses, applying, designing experiments, and communicating. The result shows that a science process skills approach-based laboratory work instruction is categorized in the practical criteria $(82.28 \%)$.

This is an open access article under the CC-BY-SA license.

\section{INTRODUCTION}

Science Process Skills is an established scientific approach. One of application of learning activities using science process skills approach can be applied to the learning process at each stage of the experiment which is contained in the laboratory work instruction. The lab work instruction is a guidebook for the implementation of an experiment that contains procedures for the preparation, implementation, analysis of data and reporting prepared by a person or group of teaching who follow scientific writing rules (Nurussaniah et al., 2016).

The use of laboratory work instruction is one of the efforts in realizing the goal of national education in Article number three which is contained in Low No. 20 of 2003 on National Education System that develops students' skills in possessing the skills, creativity and independent nature. Some of the laboratory work instruction have been developed to improve student skills include geopark-based laboratory work instruction with inquiry learning approach (Vitdiawati, et al., 2016), guided inquiry-laboratory work instruction (Munika, et al., 2014), and laboratory work-based scientific approach
(Budiarti, et al., 2014).

Based on the needs analysis that has been done, it is necessary to develop Science Process Skills-based Laboratory Work Instruction. The selection of science process skills approach is based on the learning process that must get the learning directly in developing the skills and applying the previous learnt theory. Therefore this study aims to develop a Science Process Skills Approach-based Laboratory Work Instruction is valid and practical to achieve student's experiment design ability.

\section{METHODS}

Laboratory work instruction is the guideline of laboratory work containing preparation procudure, data analysis and reporting arranged by a person or group of teaching staffs following scientific rules (Nurussaniah, 2016). Laboratory activities constitute the part of teaching and learning activities. It shows that how important the laboratory activities for the acheivement of the science is. Woolnough and Allsop in (Handayani, 2011) stated that there are four important reasons in laboratory 
activities.

The selection of research subject using simple random technique, sample of six classes of level XI MIPA in Senior High School 2 Tanjungpinang, 40 students were selected as sample in the research. This research used qualitative data that have been analysed from the percentage of quiestionnair results at validation and practicality stage. This research implemented Research and Development using 4-D development model consist of four stages namely define, design, develop and disseminate. However, in this study is limited until the third stage (develop).

The reaseach prosedure as shown as follow:

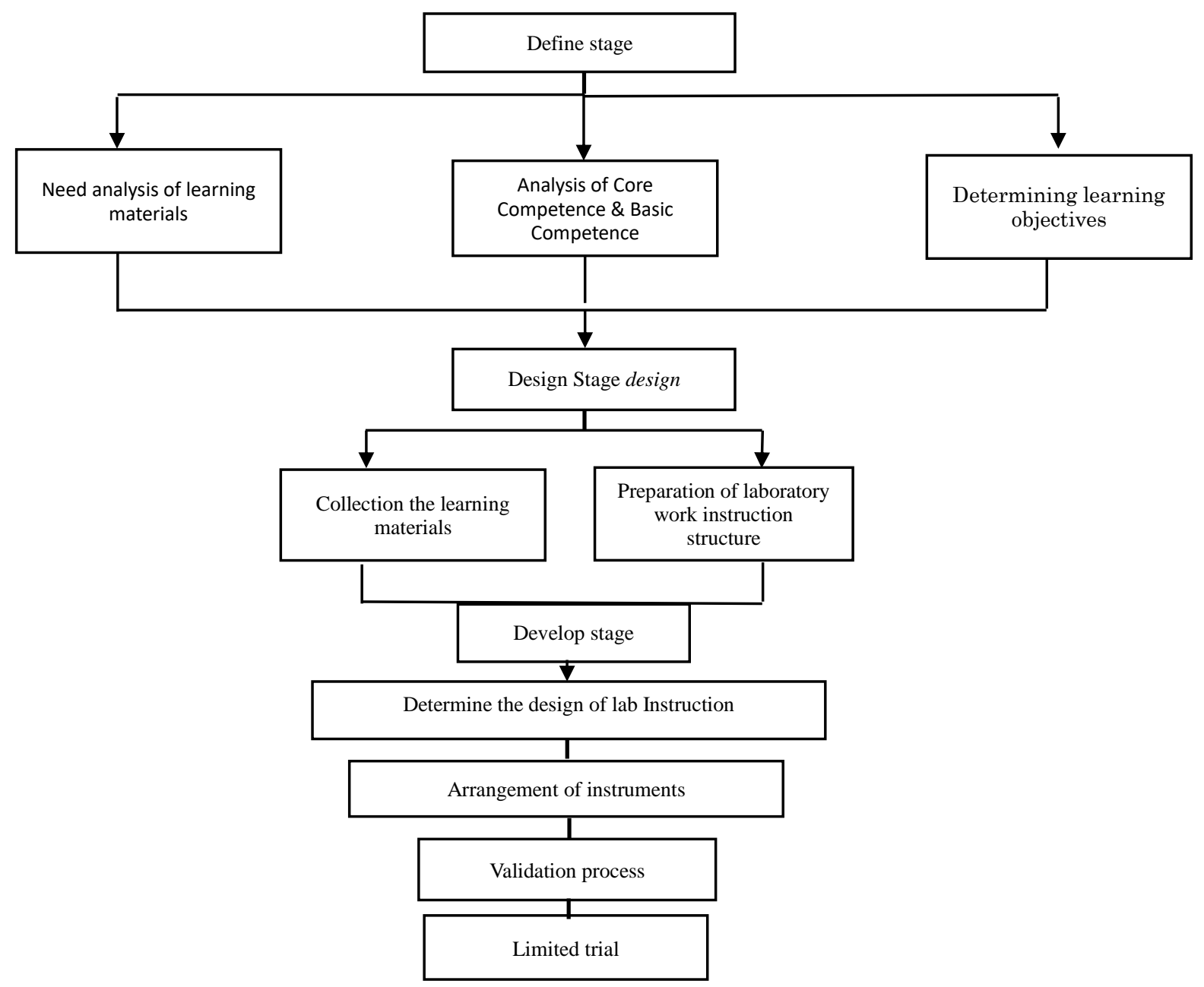

Figure 1. Research Procedure

Determination of the quality of practical Instruction using data analysis techniques described as follows:

a. Validation of Science Process Skills Approach-based Laboratury Work Instruction

The validation data on the obtained laboratory work instruction is presented with Likert scale and then the determined percentage value by using the formula according to Fauzi (2015):

Validation Percentage $=\frac{\text { Calculated Score }}{\text { Max Score }} .100 \%$

Equation (1)

The result of percentage obtained is converted into the level of validity criteria according to Fithryah et. al., (2013). The determination of validity level is given in Table 1 .
Table 1. Criteria of Degree of Validity

\begin{tabular}{ccc}
\hline Percentage $(\%)$ & Validation Criteria & Explanation \\
\hline $80-100$ & Very valid & No Revision \\
$66-79$ & Valid & No Revision \\
$56-65$ & Enough & No Revision \\
$40-55$ & Poor & Revision \\
$30-39$ & Not valid & Revision \\
\hline
\end{tabular}

b. Practicality of Science Process Skills Approach-based Laboratory Work Instruction

Student's response data on the laboratory work instruction obtained from questionnaire analyzed practicality value by using the formula by Majid (2014). 
Practicality Percentage $=\frac{\text { Calculated Score }}{\text { Max Score }} .100 \%$

Equation (2)

The result of the percentage obtained was converted into the level of practicality category according to Sudjana (2006), the determination of the category of practicality is determined in Table 2 .

Table 2. Criteria of Practical Category

\begin{tabular}{cc}
\hline Achievement Level $(\%)$ & Category \\
\hline $90-100$ & Very Practical \\
$80-89$ & Practical \\
$65-79$ & Enough Practical \\
$55-64$ & Poor practical \\
$0-54$ & Not Practical \\
\hline
\end{tabular}

Students' achievement in designing the experiment was calculated from the questionnaire of the observation using the percentage formula according to Sanjaya (2016):

Achievement percentage $=\frac{\text { Calculated Score }}{\text { Max Score }} .100 \%$

Equation (3)

\section{RESULTS AND DISCUSSION}

Needs analysis has been done to find out the initial condition of instruction manual that has been used by the students during the learning process by practicum

Table 3. Analysis of Linkage of Csore Competence (KI) and Basic Competence (KD) to Competency Achievement Indicator (IPK)

\begin{tabular}{|c|c|c|c|}
\hline Core Competence (KI 4) & $\begin{array}{l}\text { Basic competencies } \\
\text { (KD 4.4) }\end{array}$ & $\begin{array}{l}\text { Indicators of Competency Achievement } \\
\text { (GPA) }\end{array}$ & Material \\
\hline $\begin{array}{l}\text { Processing, reasoning and creating } \\
\text { in the realm of concrete and } \\
\text { abstract realms related to the } \\
\text { development of the learning in } \\
\text { school independently and acting } \\
\text { effectively and creatively and able } \\
\text { to use methods according to } \\
\text { scientific rules. }\end{array}$ & $\begin{array}{l}\text { Summarizes the } \\
\text { results of } \\
\text { thermochemical } \\
\text { experimental data } \\
\text { analysis at fixed } \\
\text { pressure }\end{array}$ & $\begin{array}{l}\text { 4.4.1. Conducting experiments on } \\
\text { determining the heat of reaction at constant } \\
\text { pressure using simple calorimetry } \\
\text { 4.4.2. Able to analyze the results of } \\
\text { experiments on the determination of reaction } \\
\text { heat at fixed pressure using simple } \\
\text { calorimetry }\end{array}$ & $\begin{array}{l}\text { Determination of } \\
\text { changes in the enthalpy } \\
\text { of the reaction of } \\
\text { calorimetry }\end{array}$ \\
\hline
\end{tabular}

Based on the needs analysis that has been done in the previous research, the subject matter of the lesson chosen for the process of developing the laboratory work instruction based on science process skills approach is "Change of Entalpy of Calorimetry Reaction". The subject matter is chosen because there is a good potential to conduct experiments and can generate the activity and creativity of students in the learning process.

The aspects assessed in the validation process include feasibility of content, language, presentation, graphical and science process skills. In developing the laboratory work instruction there are several suggestions from the validator described in Table 4.

Table 4. Validation suggestions by Validators

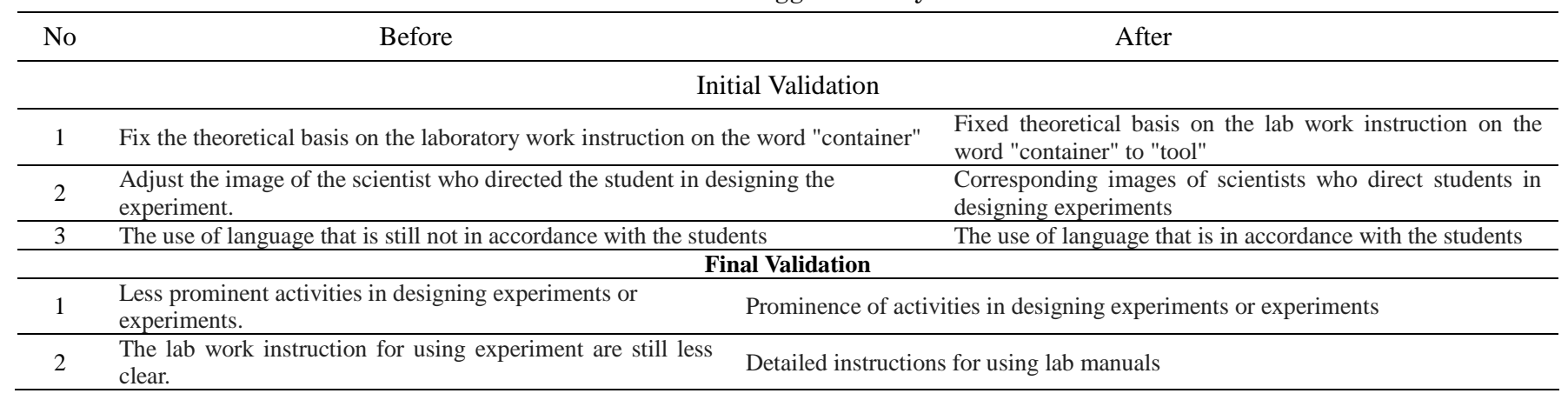

(Source: Research Results) 
The suggestions from validators are useful for improving developed laboratory work instruction (Khoirunnisa, et al., 2017). After the improvement is found the validation value of the laboratory work instruction is $92,46 \%$ with very valid criteria, content aspect is $90 \%$, linguistic aspect $93.33 \%$, presentation aspect $93.33 \%$, graphical aspect $94 \%$, and science process skill aspect equal to $91.57 \%$.

Table 5. Percentages of Validator's Ratings

\begin{tabular}{clcc}
\hline No. & \multicolumn{1}{c}{ Measured aspects } & Average Percentage & Criteria \\
\hline 1. & Feasibility of Content & 90 & Very Valid \\
2. & Language & 93,33 & Very Valid \\
3. & Presentation & 93,33 & Very Valid \\
4. & Graphical & 94 & Very Valid \\
5. & Science process skills & 91,57 & Very Valid \\
\hline & $\quad$ Average & 92,46 & Very Valid \\
\hline
\end{tabular}

(Source: Research Results)

After being validated, the laboratory work instruction was tested on 40 students. This test is done by using student response data obtained from the student's questionnaire data. The result of the percentage of content feasibility aspect is $80.58 \%$, language aspect is $86.1 \%$, presentation aspect is $81.5 \%$, graphical aspect is $85.38 \%$ and science process skills aspect is $77.85 \%$. It showed that Science Process Skills Approach-based Laboratory Work Instruction has been been developed is in practical category to be implemented in teaching process. The same research has been performed by other research by Meli, dkk (2013), stating that the Science Process Skills Approach is able to improve student learning achievement.

Table 6. The Results of Student's Response

\begin{tabular}{cccc}
\hline No. & Measured Aspects & Average Percentage & Criteria \\
\hline 1. & Feasibility of Content & 80,58 & Practical \\
2. & Language & 86,1 & Practical \\
3. & Presentation & 81,5 & Practical \\
4. & Graphical & 85,38 & Practical \\
5. & Science process skills & 77,85 & Enough Practical \\
\hline
\end{tabular}

(Source: Research Results)

\section{CONCLUSION}

Based on the result of the research, it is concluded that the design of the science process skills approach-based laboratory work instruction that has been developed has passed validation test stage and got very valid result with validation value $92,46 \%$ and practicality value $82,28 \%$. These results indicate that the developed Laboratory Work Instruction is feasible and practical to be used in achieving the ability to design student experiments on Heat of Reaction topic in Chemistry subject.

\section{Acknowledgments}

Thank you to the Head of Senior High School 2 Tanjungpinang, Chemistry Teacher of SMA Negeri 2 Tanjungpinang, and colleagues in Study Programm of Chemistry Education, FKIP UMRAH, Tanjungpinang, for the time and thought contribution in completing this research.

\section{REFERENCES}

Arikunto, S. (2010). Prosedur Penelitian Suatu Pendekatan Praktik. Jakarta: Rineka Cipta
Budiarti., W. \& Oka, A., A. (2014). Pengembangan Petunjuk Praktikum Biologi Berbasis Pendekatan Ilmiah (Scientific Approach) Untuk Siswa Kelas XI Semester Genap Tahun 2013/2014, Jurnal Pendidikan Biologi, 5, (2), 123-130.

Fithriyah, I. \& A.R As'ari. (2013). Pengembangan MediaPembelajaran Buku Saku Materi Luas Permukaan Bangun Ruang Untuk Jenjang SMP. Skripsi. Malang: Universitas Malang.

Hamalik, O. (2013). Kurikulum dan Pembelajaran ed 1 cet 13. Jakarta: Bumi Aksara.

Handayani, D., F. (2011). Meningkatkan Pemahaman Konsep Siswa Melalui Pendekatan Keterampilan Proses Pada Konsep Laju Reaksi. Skripsi. Universitas Islam Negeri Syarif Hidayatullah. Jakarta.

Khoirunnisa, F \& Sabekti, A., W. (2017). Validitas dan Praktikalitas Modul Strategi Pembelajaran Kimia Dengan Pendekatan Daur Belajar Enam Fase. Jurnal Zarah, 5,2,21-24.

Meli, S., etc. (2013). Peningkatan Keterampilan Proses Sains Siswa SMA Melalui Pembelajaran Praktikum Berbasis Inkuiri pada Materi Laju Reaksi. Jurnal Riset Dan Praktik Pendidikan Kimia. 1 (1), pp.69-75

Munika, Mujamil, J, \& Desi. (2014). Pengembangan Petunjuk Praktikum Larutan Asam Basa Bebasis Inqiury 
Pada Mata Kuliah Praktikum Kimia Dasar II Di FKIP Universitas Sriwijaya, Jurnal penelitian pendidikan Kimia, 1,2,176-188.

Nurussaniah \& Nurhayati. (2016). Pengembangan Penuntun Praktikum Fisika Dasar I Berbasis Guided Inquiry Untuk Meningkakan Kemampuan Berpikir Kritis Mahasiswa. Prosiding Seminar Nasional Fisika. Universitas Negeri Jakarta. Fak. MIPA, Jakarta, 05. Oktober 2016: hlm 63-68.

Riduwan. (2008). Skala Pengukuran Dimensi-Dimensi Penelitian. Bandung: Alfabeta.

Sudjana, N. (2006). Penilaian Hasil Belajar Mengajar. Bandung: Remaja Rosdakarya.

Vitdiawati, R., Nusantari, R., \& Tyas, D., N. (2016). Pengembangan Petunjuk Praktikum Berbasis Geopark Dengan Pendekatan Inquiry Learning Untuk Mata Kuliah Ekologi. Prosiding Symposium On Biology Education. Universitas Ahmad Dahlan. Program Studi Pendidikan Biologi, 27 agustus 2016: hlm 301-310. 